University of Nebraska - Lincoln

DigitalCommons@University of Nebraska - Lincoln

Faculty Publications, Department of Psychology

Psychology, Department of

February 2003

\title{
Measuring Damages for Lost Enjoyment of Life: The View from the Bench and the Jury Box
}

\author{
Susan Poser \\ University of Nebraska College of Law, sposer1@unl.edu \\ Brian H. Bornstein \\ University of Nebraska-Lincoln, bbornstein2@unl.edu \\ Erinn Kiernan McGorty \\ University of Nebraska-Lincoln
}

Follow this and additional works at: https://digitalcommons.unl.edu/psychfacpub

Part of the Psychiatry and Psychology Commons

Poser, Susan; Bornstein, Brian H.; and McGorty, Erinn Kiernan, "Measuring Damages for Lost Enjoyment of Life: The View from the Bench and the Jury Box" (2003). Faculty Publications, Department of Psychology. 147.

https://digitalcommons.unl.edu/psychfacpub/147

This Article is brought to you for free and open access by the Psychology, Department of at DigitalCommons@University of Nebraska - Lincoln. It has been accepted for inclusion in Faculty Publications, Department of Psychology by an authorized administrator of DigitalCommons@University of Nebraska - Lincoln. 


\title{
Measuring Damages for Lost Enjoyment of Life: The View from the Bench and the Jury Box
}

\author{
Susan Poser, College of Law, University of Nebraska-Lincoln \\ Brian H. Bornstein, University of Nebraska-Lincoln \\ Corresponding author: bbornstein2@unl.edu
}

E. Kiernan McGorty, University of Nebraska-Lincoln

\begin{abstract}
Civil jury instructions are inconsistent in defining what constitutes noneconomic damages, which may include pain, suffering, disability, disfigurement, and loss of enjoyment of life (LEL), among other injury sequelae. This inconsistency has been manifested recently in court decisions that have considered whether LEL should be treated as a separate element of noneconomic damages, distinct from pain and suffering. This paper reviews the case law on this issue and also describes a jury simulation experiment. Mock jurors awarded damages after they received instructions on noneconomic damages in which LEL was (1) not identified as a distinct element of damages; (2) defined as an element of damages distinct from pain and suffering, but participants awarded a single amount for noneconomic damages; or (3) defined as a distinct element of damages, and participants awarded separate amounts for LEL and pain and suffering. Instructions about LEL resulted in larger awards, but only when mock jurors also made a separate award for that element of damages.
\end{abstract}

Key words: noneconomic damages, pain and suffering, juries, emotional distress

The recovery of damages for noneconomic injuries has a lengthy and controversial history (O'Connell \& Bailey, 1972). Although there is some debate about whether to abolish or sharply curtail plaintiffs' ability to recover noneconomic damages (Calfee \& Rubin, 1992; Geistfeld, 1995; Jaffe, 1953; Morris, 1959; Plant, 1958), some degree of compensation for psychological injury is now almost universal. Because these damages are impossible to quantify by any standard measurement, it is an area where the jury has substantial discretion that is not particularly amenable to principled judicial review. For this reason, judges have long feared overcompensation of injured plaintiffs by sympathetic juries and have accordingly tried to create standards to constrain that discretion before the fact- that is, to limit the type of proof necessary and the circumstances under which noneconomic damages can be awarded. We see this most clearly with tort claims that involve only emotional distress, such as the tort of 
Intentional Infliction of Emotional Distress, where the standard to state a claim requires not only "severe emotional distress," to the plaintiff, but also "extreme and outrageous conduct" by the defendant (Restatement of Torts 2nd, 846).

Controversy over emotional distress damages is not limited to independent claims for emotional distress. It extends to, and is more common for, claims for emotional distress that are parasitic on claims for personal injury (Perrin \& Sales, 1993). Although there are numerous categories of emotional distress damages, ${ }^{1}$ the two main categories are pain and suffering, and loss of enjoyment of life (LEL; also referred to as "hedonic" damages). Pain and suffering is usually associated with feelings of physical pain, as well as anxiety, depression, worry, fright, grief, and humiliation (Fantozzi v. Sandusky Cement Prod. Co., 1992). LEL damages, on the other hand, are intended to compensate "for the limitations on the person's life created by the injury" (Thompson v. National Railroad Passenger Corp., 1980, p. 824). These include normal, daily activities as well as special interests and hobbies previously enjoyed (Bennett v. Lembo, 2000; Boan v. Blackwell, 2001; McDougald v. Garber, 1989). One way of conceptualizing the distinction is that pain and suffering refers principally to the occurrence of new, negative harms resulting from an injury (e.g., pain, distress) whereas LEL refers to the loss of previously enjoyed positive capacities (Coyle, 2001; "Loss of enjoyment of life as a separate element of damages," 1981).

Thus, a plaintiff who was injured in a car accident due to the negligence of the defendant might be able to collect damages for "any pain, discomfort, fears, anxiety or other mental or emotional distress" he has suffered and will likely suffer as a result of the accident. In addition, under the rubric of LEL, the plaintiff might also seek compensation for his "inability. . . to carry on and enjoy life in a manner had the accident not occurred" (Bennett v. Lembo, 2000, p. 497). In one case, evidence as to current and future loss of enjoyment included the following:

The plaintiffs and their children testified that after the accident, Mr. Bennett ceased engaging in many activities, including taking long vacations by car with his wife who does not drive, frequently visiting his daughter and grandchildren on Cape Cod, lifting weights, attending aerobics classes with his wife, wrestling with his grandchildren and coaching them in sports, mowing the lawn, and assisting his children with their home improvement projects. (Bennett v. Lembo, 2000, p. 496)

In another case, the court distinguished pain and suffering, which "encompasses the physical discomfort caused by an injury," from LEL, describing the latter as including "daily life activities that are common to most people" including "going on a first date, reading, debating politics, the sense of taste, recreational activities, and family activities" (Kansas City Southern Ry. v. Johnson, 2001, p. 381).

\section{THE CASE LAW ON LOST ENJOYMENT OF LIFE}

The difficulty in quantifying noneconomic damages has not prevented judges from making assumptions about their quantification. A review of the case law reveals that there is a common assumption that the overall monetary award for noneconom-

${ }^{1}$ For example, emotional distress damages may include a separate category of "permanent impairment" as in Bennett v. Lembo (2000); "physical impairment" as in Wal-Mart Stores v. Holland (1997); and "permanent disability" as in Swiler v. Baker's Super Market (1979). 
ic harm will be higher if damages for pain and suffering, on the one hand, and damages for LEL, on the other hand, are treated by the jury as separate elements leading to separate compartmentalized damage awards (Canfield v. Sandock, 1990; Leiker v. Gafford, 1989; McDougald v. Garber, 1989). In this paper, we review the current status of this issue and test this assumption with a jury simulation experiment.

Most courts allow the parties to present evidence of and advocate for both types of damages (Hermes, 1987). Thus, the injured plaintiff can testify about the pain and anxiety that her injury has caused her and about all of the life activities in which she can no longer participate because of the injury. But there is a division among courts about whether the jury should be instructed to consider these as separate categories of damages that lead to separate and distinct monetary awards, or whether the jury should lump the two types of emotional injuries together for the purposes of making a monetary award. At present, it appears that a majority of courts that have addressed this issue have adopted the former approach whereas a substantial minority of courts do not allow for the separate treatment of damages for LEL (American Law Reports, 1984/2000; Hermes, 1987). The trend in recent years has been for courts increasingly to allow LEL as a separate element of damages (American Law Reports, 1984/2000).

As mentioned previously, a recurring rationale offered by judges for treating LEL and pain and suffering damages together is that to do otherwise would result in higher, and therefore duplicative, damages, leading to overcompensation of the plaintiff. ${ }^{2}$

Many courts have made this assertion without any apparent evidence of its accuracy, or of how they arrived at this conclusion. The Kansas Supreme Court, for example, after recognizing that LEL is "arguably distinct from pain and suffering," simply stated that, "[i]n the majority of cases loss of enjoyment of life as a separate category of damages would result in a duplication or over lapping of damages" (Leiker v. Gafford, 1989, pp. 339, 340; see also Fireboard v. Pool, 1991). The New York Court of Appeals asserted that nonpecuniary damages would increase if loss of enjoyment was a separate category, arguing that the fact " $[\mathrm{t}]$ hat separate awards are advocated by plaintiffs and resisted by defendants is sufficient evidence that larger awards are at stake here" (McDougald v. Garber, 1989, p. 2.57). The McDougald court characterized these larger awards as a further "distortion" of the inaccuracies inherent in emotional distress damages. This sentiment was echoed by the Indiana Supreme Court, which stated, "we think instructions which define loss of 'quality and enjoyment of life' as a separate element of damages send a jury to its deliberations too unconstrained with respect to damages" (Canfield v. Sandock, 1990, pp. 1281-1282).

The courts that treat LEL and pain and suffering as separate elements of damages consider LEL to be conceptually distinct and therefore properly treated as an independent element of damages in the quest for full compensation (Abbinante v. O'Connell, 1996; Boan v. Blackwell, 2001; Fantozzi v. Sandusky Cement Products, 1992; Thomp-

\footnotetext{
${ }^{2}$ More compensation does not necessarily equal overcompensation, for at least two reasons. First, there is no true measuring stick to indicate how much any given noneconomic injury should be worth. Second, research shows that on the whole, plaintiffs are substantially undercompensated relative to their economic injury costs (Sloan \& Hsieh, 1990; Sloan \& van Wert, 1991); so implementing a procedure that did happen to increase total compensation might actually turn out to be more just in the sense of providing plaintiffs fuller compensation.
} 
son v. National Railroad Passenger Corp., 1980; see generally American Law Reports, 1984/2000). The judge in Thompson apparently did not see a duplication risk and opined that had loss of enjoyment been included with another element of damages, the monetary award for that element would have been higher to include the loss of enjoyment damages (Thompson v. National Railroad Passenger Corp., 1980). Thus, some judges do not believe that keeping the elements separate results in higher overall awards for noneconomic damages (see also Boan v. Blackwell, 2001).

There are other ways in which courts handle this issue that do not fall neatly into the two categories described previously, and about a dozen states have not directly addressed the issue (American Law Reports, 1984/2000).

As with any attempt to understand how decisions should best be made, it is important to distinguish between the descriptive and normative questions (Baron, 1994; Bell, Raiffa, \& Tversky, 1988). The "duplication" rationale for combining pain and suffering, and LEL under one rubric of damages tends to conflate these two questions by failing to distinguish the empirical, descriptive question (Do jury decisions about damage awards rise when pain and suffering and LEL are treated separately?) from the normative question (Should pain and suffering and LEL be treated separately?). The answer to the normative question depends at least in part on how one views the function of emotional distress damages. If one believes that these damages are only nominally compensatory and function more to provide the plaintiff vindication or solace (Jaffe, 1953), then it might be less important that LEL and pain and suffering are considered distinct. If, on the other hand, one views emotional distress damages as truly compensatory, despite difficulty in measuring them, one might be more inclined to treat them separately.

This distinction is sometimes reflected in how judges rule on the question of whether LEL and pain and suffering should be treated together or separately. Judges who have held that these types of damages should be distinct tend to justify their decisions on the basis that they are compensating different things (Abbinante $v$. O'Connell, 1996; Boan v. Blackwell, 2001; Fantozzi v. Sandusky Cement Products, 1992; Thompson v. National Railroad Passenger Corp., 1980). The pain one experiences from injuries, the argument goes, is entirely distinct from the psychic loss experienced by one who can no longer engage in one's favorite activities. One court distinguished these by denoting the former "subjective" and the latter "objective" (Boan v. Blackwell, 2001). Courts that have treated LEL and pain and suffering as one element of damages, on the other hand, usually justify this decision as the only way to avoid duplication of damages (Leiker v. Gafford, 1989; Loth v. Truck-A-Way Corp., 1998). This argument could reflect a belief that the pain and suffering experienced from the injury itself is similar to the pain and suffering experienced from the loss of pleasurable activities. It could also, however, reflect the belief that these damages are not truly compensatory and that one should therefore err on the side of limiting the legal fiction (McDougald v. Garber, 1989, p. 257).

Exploring which side of the normative debate is correct is beyond the scope of this paper. Addressing the descriptive question, however, helps to focus the normative question (Baron, 1994; Bell et al., 1988). If there is no change in the overall award when LEL and pain and suffering are treated separately, then answering the normative question will not affect outcomes. If, however, treating LEL and pain and suf- 
fering separately does significantly affect the overall award, then we will be forced to confront the normative question of what this difference reflects duplication or full compensation? The results of the jury experiment described herein sets the stage for that normative inquiry but cannot answer it.

\section{CONDUCTING RESEARCH ON HEDONIC DAMAGES}

Despite an accumulating body of research on how jurors make damage awards (for reviews, see Greene \& Bornstein, 2003; Hans, 2000; Vidmar, 1998), hedonic damages have received scant empirical attention. What research has been conducted has found that the effect of an injury on a person's lifestyle (i.e., LEL) is strongly correlated with people's (e.g., mock jurors') perceptions of the injury's severity and their noneconomic damage awards (Andrews, Meyer, \& Berla', 1996; Wissler, Evans, Hart, Morry, \& Saks, 1997). Although LEL seems like a rather nebulous concept, it can in fact be measured somewhat reliably, at least in relative terms (i.e., in comparing different injuries to one another; see Andrews et al., 1996; McNally, Meyer, \& Berla', 2001; Terman, 1995).

For example, Andrews et al. (1996) developed a "Lost-Pleasure-of-Life" scale by having practicing psychologists who were experienced in disability evaluation judge the severity of impact that a large number of behavioral descriptors of impairment (e.g., loss of bladder control, inability to play with children) would have on a person's enjoyment of life. The specific impairments clustered into four areas of functioning: practical (e.g., difficulty writing), emotional/psychological (e.g., sleep disruption), social (e.g., decreased participation in previously rewarding activities), and occupational (e.g., loss of vocational identity). Various groups of individuals (psychologists, graduate students, and undergraduates) perceived the behavioral descriptors' impact on an injured person's pleasure of life in an equivalent fashion, and subsequent research showed that the perceived hedonic impact of losing various behavioral capabilities does not differ as a function of hypothetical plaintiffs' gender or age, nor does it differ as a function of the perceiver's gender (McNally et al., 2001). ${ }^{3}$

In the present experiment, we tested assumptions about the effect of allowing LEL damages by comparing jury awards under three different approaches: allowing LEL as a separate category of noneconomic damages, distinct from pain and suffering; describing LEL and pain and suffering separately to the jury, but asking the jury to make a single award for noneconomic damages; and making no distinction between these types of damages in the jury instructions and asking the jury to make a single lumpsum award. The principal question addressed by this experiment was whether treating LEL as its own category of damages - merely conceptually or, in addition, by requiring a separate judgment—would inflate total damage awards.

${ }^{3}$ It goes without saying that perceived, and actual, LEL will, nonetheless, vary depending on plaintiffs' particular circumstances. For example, an amateur cellist who meets weekly to play with friends in a string quartet will lose more enjoyment if his injury prevents him from playing the cello than, say, an amateur cellist who plays only once or twice a year. 


\section{METHOD}

\section{Participants}

The participants were 122 law students (54\% female, $89 \%$ White, $M$ age $=24.47$, $M d n$ age $=23)$ and 77 psychology students $(64 \%$ female, $91 \%$ White, $M$ age $=21.53$, $M d n$ age $=20){ }^{4}$ The psychology students received extra course credit, whereas the law students participated as part of a class exercise. Two psychology students gave unusable data, leaving 197 total participants for analysis (38-43 per instruction condition for the law students, and 25 per condition for the psychology students).

\section{Materials}

The two-page case summary described an automobile negligence case (on the basis of Abbinante v. O'Connell, 1996), involving an inattentive driver who veered off the road and hit a pedestrian. As a result of the accident, the plaintiff, an 18-year-old woman, sustained severe back injuries (i.e., spinal curvature and rigidity along with early degenerative arthritis in the lower spine). A physician testified that the plaintiff would continue to suffer further back complications and pain because of the strain of her spine compensating for her injuries. In addition, the plaintiff complained of migraines and pain while sitting and sleeping.

The physician testified that the plaintiff's activities would be permanently limited. Because of her injuries, the plaintiff could no longer jog, run, or perform any activities that require swinging the arms. Because the plaintiff previously had played soccer and softball, enjoyed jogging and rollerblading, and participated in typical physical activities with her friends, she claimed that her life had become greatly disrupted by her injuries (i.e., that she had lost pleasure of life).

\section{Design and Procedure}

The design was a 2 (participant) $\times 3$ (instruction) between-groups factorial. After signing an informed consent form, participants read the instructions, which explained that they would be asked to imagine themselves as jurors in a case involving an automobile-pedestrian accident. The instructions also informed them that the defendant had been found liable for the plaintiff's injuries, that their jury had already determined how much to award the plaintiff for economic damages, and that their task was to award noneconomic damages.

Participants then read the case summary, at the end of which they received the judge's instructions about what they should consider when determining noneconomic damages. The instructions differed depending on condition. Participants in the unitary condition $(N=68)$ were given a definition of pain and suffering (i.e., "any pain, discomfort, fears, anxiety or other mental or emotional distress suffered by the plaintiff and any

\footnotetext{
${ }^{4}$ The law students were in their first semester of law school, had not yet covered the law of damages in their torts class, and were therefore unlikely to be significantly more "expert" than their psychology counterparts.
} 
similar suffering that would probably be experienced in the future"). In addition to receiving this definition of pain and suffering, participants in the LEL/lump sum condition $(N=66)$ and $L E L /$ separate conditions $(N=63)$ were given a definition of LEL (i.e., "the inability of the plaintiff to carry on and enjoy a life in a manner had the accident not occurred") and told that LEL is separate and distinct from pain and suffering.

Participants in the unitary and LEL/lump sum conditions were asked to award a single amount for noneconomic damages. Participants in the LEL/separate condition were asked to divide the total award into (1) damages for pain and suffering and (2) damages for LEL. Thus, the two LEL conditions differed from the unitary condition in that they distinguished conceptually between pain and suffering and LEL; they differed from each other in whether participants made a single award (LEL/lump sum) or divided the award into two separate components (LEL/separate).

After making an award, the participants gave their perceptions of the case by rating the following on 7-point scales from 1 (not at all) to 7 (extremely): the severity of the plaintiff's injuries, the severity of the plaintiff's pain and suffering, the degree to which the plaintiffs activities had been limited, and their overall perceptions of the litigants. To determine whether participants understood the judge's instructions for their condition, they were asked whether the judge's instructions specifically told them to consider LEL separate from pain and suffering (77.3-82.5\% correct, depending on condition), and they rated the comprehensibility of the instructions and their difficulty in deciding on an award amount (both 7-point scales). Participants also provided demographic information.

All participants completed the questionnaire in a classroom setting (the law students were members of two sections of torts, but they had not yet covered the concepts of negligence or damages). Participants were instructed not to look back at the case or the amount(s) they awarded. The entire procedure took approximately $20 \mathrm{~min}$ utes, at the end of which participants received a debriefing form.

\section{RESULTS}

To normalize the distribution, the damage awards were transformed logarithmically (e.g., Cather, Greene, \& Durham, 1996). Two-way ANOVAs (Instruction $\times$ Participant) were used to determine the difference between the conditions on the following variables: log of total damage award (for the LEL/separate condition, the total was the sum of the two component awards), the comprehensibility of the instructions, and their difficulty deciding an award amount. The case perception variables were analyzed by two-way MANOVAs.

\section{Damages}

Descriptive data are presented in Table 1. For the log of the total damage awards, there was a main effect of instruction, $F(2,191)=13.99, p<.001$. Post hoc comparisons (Tukey's HSD, $p<.05$ ) showed that participants in the LEL/separate condition $(M=\$ 2,566,270, M d n=\$ 1,000,000)$ gave greater awards than did those in either the 
Table 1. Variable Means as a Function of Instruction Condition $(N=197)$

\begin{tabular}{llcc}
\hline \multicolumn{1}{c}{ Variables } & Unitary & $\begin{array}{c}\text { Instruction condition } \\
\text { LEL/lump sum }\end{array}$ & LEL/separate \\
\hline Damages & & & \\
$\quad$ Raw mean & & & \\
Raw median & $\$ 561,721$ & $\$ 849,455$ & $\$ 2,566,270$ \\
Raw $S D$ & $\$ 112,500$ & $\$ 500,000$ & $\$ 1,000,000$ \\
Log mean & $\$ 1,346,522$ & $\$ 1,391,140$ & $\$ 5,456,006$ \\
& $11.70^{\mathrm{a}}$ & $12.23^{\mathrm{a}}$ & $13.59^{\mathrm{b}}$ \\
Injury severity & $M(S D)$ & $M(S D)$ & $M(S D)$ \\
Pain and suffering severity & $5.24(0.96)^{\mathrm{a}, \mathrm{b}}$ & $5.20(0.79)^{\mathrm{a}}$ & $5.57(0.93)^{\mathrm{b}}$ \\
Degree injuries limited & $5.97(1.06)^{\mathrm{a}, \mathrm{b}}$ & $5.24(1.02)$ & $5.52(0.93)$ \\
Perception of plaintiff & $4.96(1.20)$ & $5.71(1.08)^{\mathrm{a}}$ & $6.16(0.90)^{\mathrm{b}}$ \\
Perception of defendant & $3.72(0.91)$ & $3.61(0.74)$ & $5.19(1.11)$ \\
Understanding instructions & $4.50(1.44)^{\mathrm{a}}$ & $4.85(1.33)^{\mathrm{a}, \mathrm{b}}$ & $3.84(0.79)$ \\
Difficulty awarding & $5.68(1.38)$ & $5.56(1.39)$ & $5.25(1.19)^{\mathrm{b}}$ \\
\hline
\end{tabular}

Note. Variables other than damages were rated on 7-point scales (1-low, 7-high). Within a row, means with different superscripts are significantly different from one another, $p<.05$.

unitary condition $(M=\$ 561,721, M d n=\$ 112,500)$ or LEL/lump sum condition $(M=$ $\$ 849,455, M d n=\$ 500,000)$, which were statistically equivalent to each other. In the LEL/separate condition, participants awarded less for the pain-and-suffering component $(M=\$ 952,222, M d n=\$ 250,000)$ than for the lost-enjoyment component $(M=$ $\$ 1,628,905, M d n=\$ 500,000)$. There was no main effect of participant, $F(1,191)=$ 1.10 , and the interaction was also nonsignificant, $F(2,191)=2.69$.

\section{Case Perceptions}

There was a significant multivariate effect of instruction on participants' perceptions of the case, $F(10,374)=1.88, p<.05$. Neither the main effect of participant, $F(5,187)=2.07$, nor the interaction, $F(10,374)=0.96$, was statistically significant. Follow-up two-way ANOVAs indicated that instruction significantly affected participants' ratings of the severity of the plaintiff's injuries, $F(2,191)=3.85, p<.05$, and the degree to which her injuries limited her activities, $F(2,191)=3.99, p<.05$. In both cases, participants in the LEL/separate condition perceived the plaintiff more favorably than participants in the LEL/lump sum condition (Tukey's HSD, $p \mathrm{~s}<.05$; see Table 1). There was also a tendency to perceive the severity of the plaintiff's injury as greater in the LEL/separate condition than in the unitary condition (Tukey's HSD, $p=.078$ ). Finally, there was a comparable effect of instruction condition on participants' overall perception of the plaintiff, although it was also only marginally significant, $F(2,191)=2.53, p=.082$ (see Table 1). Taken as a whole, these results suggest that even though the plaintiff's injuries were identical in all conditions, the judge's instructions influenced how those injuries were perceived.

\section{Task Difficulty}

There were two measures of task difficulty: ratings of the degree to which participants understood the judge's instruction and the difficulty picking an award. For the un- 
derstanding of the judge's instructions, there was a main effect of condition, $F(2,191)$ $=5.41, p<.01$ (see Table 1 for means). Overall, participants in the LEL/separate condition reported greater understanding than did participants in the unitary condition (Tukey's HSD, $p<.05$ ); comprehension levels in the LEL/lump sum condition were intermediate and did not differ significantly from either of the other two conditions. Thus, distinguishing between LEL and pain and suffering damages confers a comprehension advantage, but only when that distinction is reflected in the verdict form. There was neither a main effect of participant nor an interaction on comprehension ratings, $F \mathrm{~s}<3.3$. The degree to which participants found it difficult to pick an award was not affected by either variable, nor was there a significant interaction. $F_{\mathrm{S}}<1.3$.

\section{DISCUSSION}

The present experiment is an attempt to address systematically the legal assumptions underlying the debate about whether or not to treat LEL as a discrete component of damages. As is true of the study of jury damage awards in general, the answer is not simple. We found that, on the one hand, distinguishing between LEL and pain and suffering does not invariably lead to higher damage awards than instructing mock jurors on pain and suffering alone, as evidenced by the equivalence between the unitary and LEL/lump sum conditions. On the other hand, distinguishing between LEL and pain and suffering conceptually and requiring mock jurors to make separate awards for these two elements of noneconomic damages does lead to higher awards, as evidenced by the difference between the LEL/separate condition and the other conditions.

Previous research has found that special verdict forms, along the lines of the LEL/separate condition, enhance juror comprehension and lead to more equitable awards (Greene \& Bornstein, 2000). Here, itemizing award components did enhance mock jurors' (reports of) comprehension, but it also increased their total awards. In contrast, merely instructing them on LEL without requiring a separate award for it - which is the standard procedure in some jurisdictions that allow damages for LEL (American Law Reports, 1984/2000; Hermes, 1987)_did not lead to higher awards than when participants were not instructed on LEL. Thus, the concept of LEL, in and of itself, does not appear to affect awards, but requiring a separate judgment for LEL does.

The observation that in this study, compartmentalizing noneconomic damages led to higher awards than when participants awarded a single lump-sum award, begs the question of whether a higher award is "better" or "worse." As noted previously, larger awards when LEL is treated as a discrete element might reflect duplication of awards, but it might not. Whether or not higher awards in circumstances where plaintiffs have suffered significant noneconomic injury are desirable is a normative question that the present data cannot answer.

Nonetheless, our data do provide an initial, descriptive step in addressing what happens when jurors are instructed on LEL. Merely instructing mock jurors that they could consider LEL in making their awards did not, in and of itself, result in larg- 
er awards. Why, then, should requiring them to award damages for LEL, apart from damages for pain and suffering, inflate the total award? One explanation is that participants had difficulty compartmentalizing the different elements of noneconomic damages. Research shows that although mock jurors can some times compartmentalize different elements of damages successfully (Cather et al., 1996; Landsman, Diamond, Dimitropoulos, \& Saks, 1998), they often fail to keep different categories of damages straight (see Greene \& Bornstein, in press, for a review). For example, their awards for some types of damages (e.g., punitive damages) may be influenced by factors (e.g., injury severity) that are relevant only to another type of damages (compensation, in the case of injury severity). In addition, barring jurors from awarding one type of damages can result in that category "spilling over" into another type of award (Anderson \& MacCoun, 1999; Greene, Coon, \& Bornstein, 2001). Participants might indeed have had difficulty keeping LEL and pain and suffering separate when they had to make separate awards.

Although it is possible that participants had a hard time segregating their subawards in the LEL/separate condition, another finding suggests an intriguing alternative explanation. Participants in the LEL/separate condition perceived the plaintiff's injuries as more severe and more limiting than participants in the other conditions, even though the description of her injuries was identical in all conditions. Thus, the instructions in the LEL/separate condition appear to have had the inadvertent effect of influencing how participants perceived the evidence in the case. Consistent with previous research (e.g., Bornstein, 1998; Bovbjerg, Sloan, \& Blumstein, 1989; Robbennolt, 2000; Wissler et al., 1997), across all conditions, there was a positive correlation between participants' damage awards and their perceptions of the plaintiff's injury severity, $r=.14, p<.06$, and the degree to which her injury limited her activities, $r$ $=.23, p<.001$. Perhaps both distinguishing LEL from pain and suffering and requiring separate awards had the effect of calling greater attention to the previous capacities that the plaintiff had lost. Consequently, her injury seemed more severe, and she was awarded greater compensation.

Indeed, it is possible that the "LEL effect" obtained in this study is the result of using a relatively pared-down mock trial, in which the plaintiff's injuries and jury instructions were especially salient. However, prior research has shown that the methodological complexity and verisimilitude of jury simulation research do not substantially affect the outcome of the research (Bornstein, 1999; Kramer \& Kerr, 1989). With respect to the plaintiff's injuries, a more realistic trial, with a flesh-and-blood plaintiff, could easily make her injuries more, rather than less, dramatic and salient. Regarding the salience of the jury instructions about LEL, it is a well-documented finding that slight variations in instructions can significantly affect jurors' comprehension and their verdicts, even when the trial materials are relatively complex (Greene \& Bornstein, 2000).

Thus, although we favor replicating the present results using more realistic materials in order to be more confident of their generality, we find no reason to suspect that the results would change. Finally, we note that the present finding that undergraduate and law student mock jurors did not differ in their verdicts confirms previous research demonstrating few systematic differences among different samples of mock jurors (Bornstein, 1999), even when some of the mock jurors are knowledgeable about law 
(Landsman \& Rakos, 1994; Vidmar \& Rice, 1993; though as noted previously, the first-semester law students used here were not especially knowledgeable).

\section{Future Directions}

The present research is but a first step in exploring how jurors award damages for LEL, and there are a number of interesting avenues for future research. For example, in cases where emotional distress is the primary cause of action, expert testimony about the extent and effects of the alleged injury is quite common (Goodman-Delahunty \& Foote, 1995; Perrin \& Sales, 1993), and it would undoubtedly be present in most LEL cases as well. A 1985 civil rights case, Sherrod v. Berry (1985), was the first case in which expert testimony was admitted for the purpose of quantifying damages for LEL in a wrongful death case. In that case, the injury was fatal and the expert was allowed to testify as to the "hedonic value" of the victim's life (Sherrod v. Berry, 1985/1988; see also Miller, 1989; Terman, 1995). Although the courts are wary of the propriety of admitting the testimony of such "hedonic" experts, such testimony has been allowed recently in Mississippi (Kansas City Southern Ry. v. Johnson, 2001), as well as in Illinois, California, and Alaska (Miller, 1989; see also Coyle, 2001).

The most common method of quantifying pain and suffering damages, attributed to the attorney Melvin Belli (e.g., Belli, 1982, §64.3), is the "per diem" method (see also Dobbs, 1973; Laughery, Paige, Bean, \& Wogalter, 2001; Werchick, 1965). According to this approach, jurors are encouraged to multiply some unit of time (e.g., a day) by a dollar amount that seems to correspond to the plaintiff's injury. The same technique could be applied to LEL. For example, a paraplegic's inability to take her nightly neighborhood walk might be estimated to be worth $\$ 5 /$ day; a plaintiff with a life expectancy of 30 more years would therefore warrant $\$ 54,570$ for future LEL $(\$ 5 /$ day $\times$ 365 days/year $\times 30$ years). Using this algorithm, relatively low rates, as in the $\$ 5 /$ day example, can translate into quite substantial total awards. ${ }^{5}$ Obviously, adding up similar computations for all of the other pleasurable activities that a paraplegic is no longer able to do could produce a hefty sum, and future research should address the effect on LEL awards of variations in how lost enjoyment is quantified (Laughery et al., 2001).

An alternative approach to calculating damages for LEL is the "willingness to pay" method. This method values an injury by analyzing, on average, how much people are willing to pay to reduce the possibility of that injury. This approach has gained broad acceptance among economists (Miller, 1989) and is used by federal agencies in creating regulatory guidelines that must rely on a cost-benefit analysis in determining which safety procedures to adopt (Miller, 1989). It has also been adapted by experts testifying about noneconomic damages for both fatal and nonfatal injuries (Mc-

\footnotetext{
${ }^{5}$ The propriety of the per diem approach is quite controversial because of concerns that it would be prejudicial, by leading jurors to treat it as evidence rather than argument. Dobbs (1973, p. 546) concludes, "Apparently the real basis of most decisions [to bar per diem arguments] is simply a distrust of the jury and a feeling that the jury will be too easily impressed by the apparent certitude of the mathematical calculations." Consequently, it is usually subject to a cautionary instruction by the judge when it is allowed (e.g., Vanskike v. ACF Industries, 1981) or sometimes prohibited altogether (e.g., Botta v. Brunner, 1958; for a review of the relevant case law, see Belli, 1982).
} 
Caffery, Kahneman, \& Spitzer, 1995; Miller, 1989), although it remains controversial in that context (Coyle, 2001) and is rarely allowed (Danner v. Mid-State Paving Co., 1965; Dunlap v. Lee, 1962). For example, the California Supreme Court rejected the notion that noneconomic damages can be measured objectively (Beagle v. Vasold, 1966). Relying on Beagle, the California Appellate Court recently rejected expert testimony that calculated damages using the "willingness to pay" method (Loth v. TruckA-Way, 1998, pp. 765-766).

Experimental research could address the effect on LEL awards of different means of quantification (e.g., per diem vs. lump sum vs. willingness to pay), different ways of expressing the per diem amount (e.g., \$24/day vs. $\$ 1 / \mathrm{hr}$ ), the source of the quantification (expert testimony, attorney argument, plaintiff's testimony), whether the defense presents an alternative quantification, and so forth. For example, attorney's arguments at trial could be explored to see if they are capable of either negating or magnifying the impact of judicial instructions that allow jurors to consider LEL.

\section{Practical and Policy Implications}

On a practical level, the empirical question of whether, and under what circumstances, treating hedonic damages as a separate element of damages inflates total damage awards is significant in a number of respects. First, it would strengthen lawyers' efforts in support of a particular approach to the matter in jurisdictions that have not yet ruled on the issue; in jurisdictions that have ruled on the issue but where it is ripe for reconsideration; or where LEL instructions are used as grounds for appealing an award as excessive.

Second, empirical data would provide lawyers with useful strategic advice about whether (and how) to emphasize LEL evidence in arguing for pain and suffering damages. As awards were higher when these elements were treated separately, plaintiffs' attorneys in jurisdictions that already separate these damage elements might want to present thorough evidence of loss of enjoyment by the plaintiff. Third, data about whether monetary awards for emotional distress are higher when these two elements of damages are treated separately should also be useful for judges and other legal policymakers. Courts and policymakers often make assumptions about juror psychology that are unsubstantiated by empirical data (Saks, 1989,1992). The present data could help courts and bar associations in drafting more effective pattern jury instructions. A better understanding of the effect of alternative approaches to jury instructions on LEL could eventually lead to clearer and more precise instructions, which would, in turn, facilitate jurors' task in assessing damages (Dock v. Pioneer Hi-Bred International, 2001).

One of the objections to LEL damages is that they are too speculative and therefore difficult for jurors to quantify (e.g., Slesinger, 1996). However, it is not clear that the task of quantifying LEL is any more speculative than the task of quantifying pain and suffering, and this same criticism has been deemed inadequate as an argument for barring the latter type of damages (Dobbs, 1973; O'Connell \& Bailey, 1972). The attempt to quantify noneconomic damages, including LEL, is not a science for the simple and obvious reason that money is not commensurate with emotional stability and 
the absence of pain. There is not, and likely never will be, a market in noneconomic damages. As one group of scholars put it,

If art can acquire a market value, in principle, so can the loss of sight. The problem is that people do not normally buy and sell the sorts of sensory, motor, cognitive, and other capacities that are injured in accidents. The result is that to compensate for noneconomic losses, the law must turn to an alternative source of values, namely, the social judgment of the community, typically supplied by juries. A task that involves assigning a value to the virtually undefinable is, by definition, challenging to perform and at least as challenging to evaluate. (Wissler, Hart, \& Saks, 1999, p. 757)

Money might offer solace, or a sense of vindication, to one who is suffering emotional distress (Jaffe, 1953), but ultimately it cannot put the plaintiff in her rightful position the way, for example, money for the purchase of a new car can replace a damaged car, or money for lost wages can preserve the economic status of a plaintiff. Judges and commentators have long recognized this (McDougald v. Garber, 1989; Radin, 1993; Restatement (Second) of Torts, 1965, §903, cmt. a), and it accounts for much of the skepticism with which judges have greeted expert testimony about LEL. ${ }^{6}$ As one court recently put it, "No amount of expert testimony on the value of life could possibly help a jury decide that difficult question [of the value of LEL]. A life is not a stock, car, home, or other such item bought and sold in some marketplace" (Loth v. Truck-A-Way, 1998, p. 767).

We were recently, and tragically, reminded of the complexity of awarding these damages by the furor over the September 11 compensation scheme. As part of Section 402 (7) of the "September 11 Victim Compensation Fund of 2001," established by Title IV of the Air Transportation Safety and Stabilization Act of 2001, the term noneconomic losses is defined as "losses for physical and emotional pain, suffering, inconvenience, physical impairment, mental anguish, disfigurement, loss of enjoyment of life, loss of society and companionship, loss of consortium (other than loss of domestic service), hedonic damages, injury to reputation, and all other nonpecuniary losses of any kind or nature."

The special master in charge of promulgating rules for distribution of the fund to victims' families, Kenneth Feinberg, stating that he did not want to "play Solomon" (Pay for victims not pain-based, 2001) decided to give a set amount of noneconomic damages to each victim and to each victim's spouse and children (the final amounts were $\$ 250,000$ per victim and $\$ 100,000$ for spouse and each child), rather than try to determine on a case-by-case basis the level of suffering of each claimant. The storm of protest that this decision set off illustrates the centrality, and complexity, of noneconomic damages in current tort litigation. Many of the comments on the Interim Final Rule contended that this amount of money for noneconomic damages is woefully inadequate and much more is routinely awarded in court. ${ }^{7}$ News reports confirm that the perceived inadequacy of the noneconomic damages is one of the reasons many of the victims' families may choose not to be compensated by the fund and instead to take their chances in court (O'Brien, 2002).

${ }^{6}$ One court dismissed this objection by pointing out that " $[\mathrm{t}]$ he rule against recovery of 'speculative damages' is generally directed against uncertainty as to cause rather than uncertainty as to measure or extent" (Sherrod v. Berry, 1985/1988, p. 164).

${ }^{7}$ See http://www.usdoj.gov/victimcompensation/interim_03n.html for comments on the Interim Final Rule. 


\section{CONCLUSION}

Debate about duplication of damages, and over and undercompensation for noneconomic harms, is at one level a debate about intuition, about what feels like too much or too little compensation for a particular emotional reaction, whether it be pain, humiliation, grief, or the loss experienced by one who can no longer play with her grandchildren. The jury experiment described in this paper is an attempt to measure those intuitions, but not to assess their accuracy. Our findings suggest that jury awards for noneconomic damages are indeed higher when mock jurors are asked to make separate awards for pain and suffering and LEL, and that this effect is mediated by differences in how the plaintiff's injury is perceived as a function of the judicial instructions.

\section{REFERENCES}

Abbinante v. O’Connell, 662 N.E.2d 126 (Ill. App. 1996).

American Law Reports. (1984/2000). Loss of enjoyment of life as a distinct element or factor in awarding damages for bodily injury. 34 A.L.R. 4th 293 et seq.

Anderson, M. C., \& MacCoun, R. J. (1999). Goal conflict in juror assessments of compensatory and punitive damages. Law and Human Behavior, 23, 313-330.

Andrews, P., Meyer, R. G., \& Berla', E. P. (1996). Development of the lost pleasure of life scale. Law and Human Behavior, 20, 99-111.

Baron, J. (1994). Thinking and deciding (2nd ed.). Cambridge: Cambridge University Press.

Beagle v. Vasold, 65 Cal.2d 166 (1966).

Bell, D. E., Raiffa, H., \& Tversky, A. (Eds.). (1988). Decision making: Descriptive, normative, and prescriptive interactions. Cambridge: Cambridge University Press.

Belli, M. (1982). Modern trials (2nd ed.). St. Paul, MN: West.

Bennett v. Lembo, 761 A.2d 494 (N.H. 2000).

Boan v. Blackwell, 541 S.E.2d 242 (S.C. 2001).

Bornstein, B. H. (1998). From compassion to compensation: The effect of injury severity on mock jurors' liability judgments. Journal of Applied Social Psychology, 28, 1477-1502.

Bornstein, B. H. (1999). The ecological validity of jury simulations: Is the jury still out? Law and Human Behavior, 23, 75-91.

Botta v. Brunner, 138 A.2d 713 (N.J. 1958.).

Bovbjerg, R. R., Sloan, F. A., \& Blumstein, J. F. (1989). Valuing life and limb in tort: Scheduling "pain and suffering." Northwestern University Law Review, 83, 908-976.

Calfee, J. E., \& Rubin, P. H. (1992). Some implications of damage payments for nonpecuniary losses. Journal of Legal Studies, 21, 371-411.

Canfield v. Sandock, 563 N.E. 2d 1279 (Ind. 1990).

Cather, C., Greene, E., \& Durham, D. (1996). Plaintiff injury and defendant reprehensibility: Implications for compensatory and punitive damage awards. Law and Human Behavior, 20, 189-205.

Coyle, M. (2001, April 9). Updating "hedonic" damages. National Law Journal, pp. A1, A15.

Danner v. Mid-State Paving Co., 173 So.2d 608 (Miss. 1965).

Dobbs, D. B. (1973). Handbook on the law of remedies. St. Paul, MN: West.

Dock v. Pioneer Hi-Bred International, 2001 WL 710118 (Iowa App. 2001).

Dunlap v. Lee, 126 S.E.2d 62 (N.C. 1962).

Fantozzi v. Sandusky Cement Prod. Co., 597 N.E.2d 474 (Ohio 1992).

Fireboard Corp. v. Pool, 813 S.W.2d 658 (Tex. App. 1991).

Geistfeld, M. (1995). Placing a price on pain and suffering: A method for helping juries determine tort damages for nonmonetary injuries. California Law Review, 83, 773-852. 
Goodman-Delahunty, J., \& Foote, W. E. (1995). Compensation for pain, suffering, and other psychological injuries: The impact of Daubert on employment discrimination claims. Behavioral Sciences and the Law, 13, 183-206.

Greene, E., \& Bornstein, B. (2000). Precious little guidance: Jury instruction on damage awards. Psychology, Public Policy, and Law, 6, 743-768.

Greene, E., \& Bornstein, B. H. (2003). Determining damages: The psychology of jury awards. Washington, DC: American Psychological Association.

Greene, E., Coon, D., \& Bornstein, B. (2001). The effects of limiting punitive damage awards. Law and Human Behavior, 25, 217-234.

Hans, V. P. (2000). Business on trial: The civil jury and corporate responsibility. New Haven, CT: Yale University Press.

Hermes, P. J. (1987). Loss of enjoyment of life-Duplication of damages versus full compensation. North Dakota Law Review, 63, 561-600.

Jaffe, L. L. (1953). Damages for personal injury: The impact of insurance. Law and Contemporary Problems, 18, 219-240.

Kansas City Southern Railway v. Johnson, 798 So.2d 374 (Miss. 2001).

Kramer, G. P., \& Kerr, N. L. (1989). Laboratory simulation and bias in the study of juror behavior: A methodological note. Law and Human Behavior, 13, 89-99.

Landsman, S., Diamond, S., Dimitropoulos, L., \& Saks, M. J. (1998). Be careful what you wish for: The paradoxical effects of bifurcating claims for punitive damages. Wisconsin Law Review, 1998, 297342 .

Landsman, S., \& Rakos, R. (1994). A preliminary inquiry into the effect of potentially biasing information on judges and jurors in civil litigation. Behavioral Sciences and the Law, 12, 113-126.

Laughery, K., Paige, D., Bean, R., \&Wogalter, M. (2001, October). Pain and suffering awards for consumer product accidents: Effects of suggesting day-rate information. In Proceedings of the Human Factors and Ergonomics Society 45th Annual Meeting, Minneapolis, pp. 843-847.

Leiker v. Gafford, 245 Kan. 324 (1989).

Loss of enjoyment of life as a separate element of damages. (1981). Pacific Law Journal, 12, 965-986.

Loth v. Truck-A-Way Corp., 60 Cal. App. 4th 757 (1998).

McCaffery, E. J., Kahneman, D. J., \& Spitzer, M. L. (1995). Framing the jury: Cognitive perspectives on pain and suffering awards. Virginia Law Review, 81, 1341-1420.

McDougald v. Garber, 73 N.Y.2d 246 (1989).

McNally, N. A., Meyer, R. G., \& Berla', E. P. (2001, August). The lost pleasure of life scale: Ranking of behavioral descriptors. Paper presented at the meeting of the American Psychological Association, San Francisco.

Miller, T. R. (1989). Willingness to pay comes of age: Will the system survive? Northwestern University Law Review, 83, 876-907.

Morris, C. (1959). Liability for pain and suffering. Columbia Law Review, 59, 476-485.

O'Brien, T. (2002, February 1). Cracks in the plaintiff bar's solidarity: Sept. 11 survivors caught between competing brands of legal advice. The Legal Intelligencer, 226, p. 4.

O'Connell, J., \& Bailey, T. (1972). The history of payment for pain and suffering. University of Illinois Law Forum, 1972, 83-109.

Pay for victims not pain-based. (2001, December 19). New York Law Journal, 226, p. 7.

Perrin, G., \& Sales, B. D. (1993). Artificial legal standards in mental/emotional injury litigation. Behavioral Sciences and the Law, 11, 193-203.

Plant, M. L. (1958). Damages for pain and suffering. Ohio State Law Journal, 19, 200-211.

Radin, M. J. (1993). Compensation and commensurability. Duke Law Journal, 43, 56-86.

Restatement (Second) of Torts. (1965). St. Paul, MN: American Law Institute.

Robbennolt, J. K. (2000). Outcome severity and judgments of "responsibility": A meta-analytic review. Journal of Applied Social Psychology, 12, 2575-2609.

Saks, M. J. (1989). Legal policy analysis and evaluation. American Psychologist, 44, 1110-1117. 
Saks, M. J. (1992). Do we really know anything about the behavior of the tort litigation system-And why not? University of Pennsylvania Law Review, 140, 1147-1292.

Sherrod v. Berry, 629 FSupp. 159 (N.D. Ill. 1985), rev.'d on other grounds.

Sherrod v. Berry, 856 F.2d 802 (7th Cir. 1988).

Slesinger, R. E. (1996). The demise of hedonic damages claims in tort litigation. Journal of Legal Economics, 6, 17-26.

Sloan, F. A., \& Hsieh, C. R. (1990). Variability in medical malpractice payments: Is the compensation fair? Law and Society Review, 24, 997-1039.

Sloan, F. A., \& van Wert, S. S. (1991). Cost and compensation of injuries in medical malpractice. Law and Contemporary Problems, 54(1), 131-168.

Swiler v. Baker's Super Market, 203 Neb. 183 (1979).

Terman, S. A. (1995). Emotional damages due to wrongful death—What are they worth? Behavioral Sciences and the Law, 13, 43-59.

Thompson v. National Railroad Passenger Corp., 621 F.2d 814 (6th Cir. 1980). Applying Tennessee law.

Vanskike v. ACF Industries, 665 F.2d 188 (8th Cir. 1981).

Vidmar, N. (1998). The performance of the American civil jury: An empirical perspective. Arizona Law Review, 40, 849-899.

Vidmar, N., \& Rice, J. J. (1993). Assessments of noneconomic damage awards in medical negligence: A comparison of jurors with legal professionals. Iowa Law Review, 78, 883-911.

Wal-Mart Stores v. Holland, 956 S.W.2d 590 (Tex. App. 1997).

Werchick, J. W. (1965). Unmeasurable damages and a yardstick. Hustings Law Journal, 17, 263-300.

Wissler, R. L., Evans, D. L., Hart, A. J., Morry, M. M., \& Saks, M. J. (1997). Explaining "pain and suffering" awards: The role of injury characteristics and fault attributions. Law and Human Behavior, 21, 181-207.

Wissler, R. L., Hart, A. J.,\& Saks, M. J. (1999). Decision making about general damages: A comparison of jurors, judges, and lawyers. Michigan Law Review, 98, 751-826. 